\title{
Technika opracowania błękitów w malarstwie gdańskim od połowy XVI do końca XVIII w.
}

Wśród błękitnych pigmentów stosowanych w gdańskiej palecie malarskiej okresu od połowy XVI do końca XVIII w. należy wymienić trzy podstawowe pigmenty nieorganiczne: azuryt naturalny, ultramaryna naturalna i smalta oraz błękitny pigment organiczny - indygo ${ }^{1}$. Najdroższy z nich -

1 Warsztat malarski artystów gdańskich poddany był szerokiemu zakresowi interdyscyplinarnych badań prezentowanych w: J. Olszewska-Świetlik, Technologia i technika malarska mybranych nowożytnych epitafión ₹ Bazyliki Mariackiej w Gdańsku, Toruń 2009; eadem, Gdański warsztat malarski schytku XVII i w XVIII wieku na prayketadach wybranych portretów przedstawiajacych protestanckich duchownych, Toruń 2010; B. Szmelter-Fausek, „Gdański warsztat malarski ostatniej ćwierci XVI i pierwszej połowy XVII w. na przykładzie twórczości Antona Möllera (1563/5-1611) i Hermanna Hana (1580-1627/8)", praca doktorska pod kierunkiem dr hab. Justyny Olszewskiej-Świetlik, prof. UMK, Instytut Zabytkoznawstwa i Konserwatorstwa UMK w Toruniu, Toruń 2013, wydruk komputerowy dostępny w archiwum biblioteki UMK, oraz licznych artykułach naukowych: J. Olszewska-Świetlik, B. Szmelter-Fausek, E. Pięta, E. Proniewicz, Spectroscopic and Gas Chromatographic Studies of Pigments and Binders in Gdańsk Paintings of the 17th Century, ,Journal of Spectroscopy" 2013, vol. 5, DOI: 10.1155/2013/187407; E. Pięta, E. Proniewicz, B. Szmelter-Fausek, J. Olszewska-Świetlik, Leonard M. Proniewicz, Micro-Raman spectroscopy analysis of $17^{\text {th }}$ century panel painting "Servilius Appius" by Isaac van den Blocke, ,Journal of Raman Spectroscopy" 2014, DOI: 10.1002/jrs.4489; E. Pięta, E. Proniewicz, B. Szmelter-Fausek, J. Olszewska-Świetlik, Leonard M. Proniewicz, Pigment characterization of important golden age panel paintings of the 17th century, „Spectrochimica Acta Part A: Molecular and Biomolecular Spectroscopy”, vol. 136, Part B, 5 February 2015, Pages 594-600; Elsevier; B. Szmelter-Fausek, Badania obrazón Antona Möllera i Hermanna Hana jako praycazynek do rozpoznania gdańskiego warsżtatu ma- 
ultramaryna naturalna - była stosowana w europejskim malarstwie sztalugowym w XIV i XV w., następnie w XVI w. użycie jej stopniowo zanikało. Jest to pigment otrzymywany $\mathrm{z}$ minerału lapis lazuli, który występuje łącznie $z$ takimi minerałami jak między innymi kalcyt i piryt. W XV i XVI w. głównym źródłem pozyskiwania ultramaryny był Badakhshan w Afganistanie. Ultramarynę naturalną otrzymywano przez rozdrabnianie minerału bez dodatkowego oczyszczania, co było charakterystyczne w XIII w., lub poprzez specjalną obróbkę, w celu usunięcia zanieczyszczeń, o której pisał Cennino Cennini. Ultramarynę stosowano bardzo często w spoiwach wodnych, jak gumożywica i tempera jajowa oraz w spoiwie olejnym, w którym dawała ciemny odcień błękitu, dlatego najczęściej mieszano ją z bielą ołowiowa lub stosowano jako cienki laserunek. By przyśpieszyć wolny czas wysychania w spoiwie olejnym, dodawano niekiedy drobno utartej smalty ${ }^{2}$. Azuryt naturalny był bardziej powszechnym pigmentem od ultramaryny naturalnej, szczególnie w malarstwie europejskim od XV do XVIII w. Otrzymywano go z minerału poprzez rozdrabnianie, ucieranie i przemywanie ${ }^{3}$. Smalta była rozpowszechniona w malarstwie europejskim od końca XV aż do XIX w., kiedy została wyparta przez ultramarynę sztuczną i błękit kobaltowy. W malarstwie olejnym używano ja bardzo często w mieszaninie z bielą ołowiową do malowania nieba. Smalta użyta ze spoiwem olejnym bardzo często ulegała zmianom barwnym na zielono-szary kolor. Z uwagi na zachodzace $\mathrm{w}$ warstwie smalty zmiany podawano $\mathrm{w}$ traktatach wiele wskazówek dotyczących sposobu malowania tym pigmentem. Zalecenia zawarł między innymi w traktacie z 1587 r. Palomino, Karel van Mander w Het Schilder-Boeck z 1604 r. oraz de Mayerne w manuskrypcie powstałym

larskiego ostatniej ćnierci XVI i pierwszej połowy XVII w., [w:] Historia sఇtuki w dobie globalizacji. Materialy IV Środkowoeuropejskiego Forum Doktorantón Historii Sztuki, Instytut Historii Sztuki, Wroctaw, 5-8 listopada 2009, red. A. Jezierska, A. Szewczyk, A. Śliwowska, Wrocław 2013, s. 21-29; B. Szmelter-Fausek, Wybrane obrasy ottaryowe Hermanna Hana (1580-ok. 1628) - zagadnienia technologiczne i konserwatorskie, [w:] Historia religii na Ukrainie [Icmopia pesiziŭ в Укpä̈нi], Lwów 2012, t. 2, s. 609-616.

2 Pigment Compendium: a dictionary and optical microscopy of historical pigments, N. Eastaugh [et al.], Amsterdam [etc.]: Elsevier, 2008, s. 224-226; P. Rudniewski, Pigmenty i ich identyfikacja, ASP, skrypt nr 13, Warszawa 1994, s. 50-53.

3 Pigment Compendium, op.cit., s. 39-40; P. Rudniewski, op.cit., s. 53-56. 
w latach 1620-16464. Barwnik organiczny indygo stosowany był głównie do barwienia tkanin w starożytnych Indiach, Chinach i Egipcie od ok. 4000 lat p.n.e. O barwniku pisali w swoich traktatach między innymi Pliniusz, Mnich Teofil, Cennino Cennini, wzmiankowany jest również w wielu innych rękopisach jak na przykład rękopis wenecki. Wśród artystów XVII w. stosujących indygo do malowania obrazów sztalugowych wymieniany jest Frans Hals, który podmalowywał tym pigmentem pod azurytem ${ }^{5}$.

W malarstwie gdańskim stosowano błękity najczęściej do opracowania modelunku błękitnych szat i nieba oraz w mieszaninach z innymi pigmentami do uzyskania zróżnicowanych tonów barwnych żółcieni, czerwieni, brązów i zieleni. Technikę opracowania błękitów przeanalizowano na przykładzie 27 obrazów sztalugowych, powstałych w warsztatach gdańskich w okresie od połowy XVI do końca XVIII w. i pochodzących z kościołów i muzeów Gdańska, Pelplina i Poznania. Są to: 1. Epitafium rodżiny Johanna Connerta (1554-1556), 2. Epitafum Michaela Loitza (Loytze) (1561-1564), 3. Epitafum Georga Hojera (1586) i 4. Epitafum Jacoba Schadiusa (Schade) (1588) z Bazyliki Mariackiej w Gdańsku; 5. Alegoria Pychy (ok. 1600) z Muzeum Narodowego w Gdańsku (MNG); 6. Alegoria Pychy, 7. Model śniata i 8. Alegoria Bogactwa (ok. 1600) z Muzeum Narodowego w Poznaniu; Antona Möllera 9. Grosz caynszony (1601) z Muzeum Historycznego Miasta Gdańska (MHMG) i 10. Uç̧ynki mitosierdzৃia (1607) z Bazyliki Mariackiej w Gdańsku; 11. Servilius Appius (1608) Isaaca van den Blocke z MHMG; Antona Möllera 12. Ostatnia Wieczerza i 13. Ukryyżowanie (1609-1611) z kościoła św. Katarzyny w Gdańsku; 14. Koncert anielski (1611) Hermanna Hana z Muzeum Diecezjalnego w Pelplinie; 15. Epitafum rodziny Hansa Gronau (1612), przypisane do kręgu odziaływania Antona Möllera, z bazyliki Mariackiej w Gdańsku; obrazy Hermanna Hana: 16. Chrzest Subisława i fundacja klasz̧toru w Oliwie oraz 17. Napad Prusów na klasz̧tor w Oliwie (1611) z katedry w Oliwie, 18. Pokton pasteray i 19. Wniebowriecie Najśniętszej Marii Panny (1618) z katedry w Pelplinie, 20. Koronacja Najswietszej Marii Panny (po 1624) z katedry w Oliwie oraz 21. Św. Elìbieta opatrujaca chorego (przed 1625) z katedry w Pelplinie; cztery portrety przedstawiające pastorów, eks-

4 Pigment Compendium, op.cit., s. 351-352; P. Rudniewski op.cit., s. 58-61.

5 Pigment Compendium, op.cit., s. 200-201; P. Rudniewski, op.cit., s. 50-61. 
ponowane w Muzeum Narodowym w Gdańsku: 22. Portret pastora Daniela Schmidta (ok. 1699) i 23. Portret pastora Michaela Ulmitza (ok. 1706) z warsztatu gdańskiego, 24. Portret pastora Johanna Gottfrieda Kirscha (ok. 1624) Daniela Kleina, 25. Portret nieokreślonego pastora (XVIII w.) z warsztatu gdańskiego, - obrazy z Biblioteki Gdańskiej PAN: 26. Portret Johanna Sigismunda Ferbera (1746) J. B. Hoffmanna oraz 27. Portret Gottfrieda Lengnicha (ok. 1750) J. J. Fabriciusa ${ }^{6}$.

Przeprowadzono analizy sposobów opracowania błękitów, które zestawiono w tabeli 1 . Wyniki badań pokazują zależność związaną z okresem powstania dzieł i rodzajem zastosowanych błękitnych pigmentów. W poddanych badaniom obrazach (nr 1-20) z okresu od połowy XVI do końca pierwszej ćwierci XVII w. zastosowano przede wszystkim azuryt naturalny i smaltę. Dodatkowo w czterech z nich (nr 10-13) powstałych w latach 1607-1611 zidentyfikowano ultramarynę naturalna. Analizując obrazy, w których stwierdzono obecność dwóch błękitów - azurytu naturalnego i smalty - ustalono, że tylko w jednym obrazie (nr 2) datowanym na lata 1561-1564 dominuje azuryt naturalny, a w ośmiu dziełach gdańskich (nr 3, 5-9) powstałych w 1586, ok. 1600, 1611 i po 1624 r. - dominuje smalta. Smalta była pigmentem znacznie tańszym od kosztownej ultramaryny naturalnej i łatwiej dostępnym od azurytu naturalnego. Azuryt stał się szczególnie trudno dostępny po roku 1526, kiedy Węgry - główny importer tego minerału - zostały zawładnięte przez Turków ${ }^{7}$ Błękitny pigment nieorganiczny indygo użyto jako jedyny błękit w sześciu badanych obrazach przedstawiających portrety pastorów i datowanych na koniec XVII i XVIII w.

Ultramarynę naturalna zidentyfikowano w obrazach Antona Möllera: Ucsynki mitosierdzia, Ostatnia wieczerza i Ukrayzowanie oraz Isaaca van den Blocke: Servilius Appius. Obrazy powstały na przestrzeni czterech lat od 1607 do 1611 r. Występowanie tego pigmentu jedynie w czterech spośród wytypowanych do badań obrazów może świadczyć o tym, że pigment był

${ }^{6}$ J. Olszewska-Świetlik, Technologia i technika malarska..., s. 22-102; eadem, Warsztat malarski osiemnastowiecznych portrecistów gdańskich na prayktadzie dwóch portretów z. Biblioteki gdańskiej PAN, „Gdańskie Studia Muzealne”, 7, Gdańsk 2011, s. 91-107; idem, Gdański warsðtat malarski schytku XVII $i$ w XVIII wieku..., s. 23-35, 43-54, 56, 64, 72.

7 J. P. Filedt Kok, W. Halsema-Kubes, W. Th. Kloek, Kunst voor de beeldenstorm: Noordnederlandse kunst 1525-1580: Catalogus, Rijksmuseum, Amsterdam 1986, s. 109. 
trudno osiagalny. Być może artyści zaopatrzyli się w niego podczas sugerowanej odbytej wędrówki do Niderlandów ${ }^{8}$. W XVI w. ultramaryna naturalna była pigmentem bardziej popularnym w krajach niderlandzkich niż w Niemczech. Artyści niemieccy, tacy jak Albrecht Dürer czy Łukasz Cranach Starszy, zastosowali ultramarynę w dziełach, które powstały tuż po odbytej wędrówce do Antwerpii, co sugerowałoby, że ultramarynę przywié́li ze sobą z Niderlandów. Pigment ten zastosowano do namalowania błękitnych partii w dziełach na specjalne zamówienie sądów bądź wysokich dostojników kościelnych czy państwowych' ${ }^{9}$ W obrazach gdańskich ultramarynę użyto także do opracowania wybranych błękitnych szat. W obrazie Uç⿰氵n)ki mitosierdzৃia na brązowym podmalowaniu składającym się z bieli ołowiowej, czerni organicznej i żółcieni oraz czerwieni żelazowych wykonano błękitne podmalowanie w kolorze lokalnym mieszaniną drobnozmielonego azurytu naturalnego, drobnozmielonej ultramaryny naturalnej i niewielką ilością bieli ołowiowej. Półtony i cienie opracowano azurytem o grubym ziarnie (dochodzącym do ok. $30 \mu \mathrm{m}$ ) z dodatkiem ultramaryny, w składzie której zidentyfikowano domieszkę kalcytu. W światłach do mieszaniny błękitów dodano bieli ołowiowej (il. 1). Anton Möller opracował błękity z użyciem ultramaryny także w Ostatniej Wieczersyy, gdzie farbę nałożył na białe podmalowanie oraz w obrazie Ukrayyzowanie, w którym błękity opracowane są na białym, a w niektórych partiach na brązowym podmalowaniu. We wszystkich obrazach półtony i cienie opracowano w podobny sposób mieszaniną azurytu, ultramaryny i odrobina bieli, natomiast światła podnoszono, dodając do mieszaniny większej ilości bieli ołowiowej. Isaac van den Blocke ultramarynę naturalną zastosował do opracowania błękitnych szat w mieszaninie ze smaltą i bielą ołowiowa. Warstwa malarska została nałożona na szarą imprimaturę, w składzie której zidentyfikowano czerń roślinną i biel ołowiową, czerwone podmalowanie cynobrem oraz podmalowanie w kolorze lokalnym - smaltą (il. 2). s. 177.

8 J. Tylicki, Rysunek gdanski ostatniej ćmierci XVI i pierwszej połony XVII wieku, Toruń 2005,

9 G. Heydenreich, The Leipzig Trade Fairs as a Market for Painters' Materials in the Sixteenth Century, [w:] Trade in Artists' Materials, Markets and Commerce in Europe to 1700, ed. J. Kirby, S. Nash, J. Cannon, Archetype Publications 2010, s. 297-313. 
Azuryt naturalny występuje razem ze smaltą w przypadku większości badanych obrazów z okresu od połowy XVI do pierwszej ćwierci XVII w. Wyjątek stanowią obrazy z Epitafium Jacoba Schadiusa (nr 4) z 1588 r., w których zidentyfikowano wyłącznie smaltę oraz obraz Hermanna Hana św. Elïbieta opatrujaca chorego (nr 21) datowany na lata przed 1625 r., w którym, przeciwnie, wykorzystano jedynie drugi z błękitnych pigmentów - azuryt naturalny. W Epitafum rodziny Johanna Connerta (nr 1) większość z błękitów modelowano przy użyciu drobnozmielonego azurytu naturalnego, bieli ołowiowej oraz czerni roślinnej. Azuryt naturalny zastosowano w tym dziele jako pigment wiodaccy, podobnie jak w Epitafium Michaela Loitza (nr 2). W przypadku obrazu nr 1 smaltę zidentyfikowano tylko w przypadku jednej z próbek. Błękitny pigment wraz z dodatkiem bieli ołowiowiej nałożono na błękitne podmalowanie wykonane mieszanina azurytu naturalnego, bieli ołowiowej i czerni roślinnej. W obrazie nr 2 smaltą namalowano błękitną wstążkę w postaci anioła na tablicy prawej. W Epitafium Georga Hojera (nr 3) pigmentem tym namalowano większość błękitnych partii, poza wybranymi miejscami, gdzie nakładano laserunki azurytem naturalnym. Podobnie w Alegorii Pychy (nr 5) oraz trzech obrazach z cyklu Model swiata i spoteczeństwa gdańskiego (nr 6-8) smalta dominowała jako pigment zastosowany przede wszystkim do opracowania nieba. Drobnozmielony azuryt naturalny stanowił baze przy modelowaniu roślinności, a gruboziarnisty użyto jako dodatek w mieszaninie z czerwienia organiczna - karminem do uzyskania fioletowego odcienia szaty.

W drugiej połowie XVI i na początku XVII wieku podmalowanie pod błękity było najczęściej koloru białego lub szarego (obrazy nr 1-4, $9,11,12,15)$. Niekiedy wykonywano podmalowanie w kolorze lokalnym, jak w przypadku Epitafum rodz̧iny Johanna Connerta (nr 1), do którego użyto mieszaniny azurytu naturalnego, bieli ołowiowej i czerni roślinnej. Podmalowanie w kolorze lokalnym uzyskanym z mieszaniny bieli ołowiowej i smalty zidentyfikowano w obrazach z Epitafium Georga Hojera (nr 3). W Epitafum Jacoba Schadiusa (nr 4) błękitny modelunek mieszanina smalty i bieli ołowiowej rozpoczynano od szarego podmalowania - w cieniach i w półtonach ciemną szarością, a w światłach jasna. Przyczyniło się to do powstania kontrastów między błękitem i jasnymi prawie białymi światłami a ciemna szarością. W obrazach przypisywanych malarzowi gdańskiemu z kręgu Hermanna Hana (?) (nr 5, 6-8), datowanych na ok. 1600 r. zidentyfikowano 
brązową imprimaturę, charakterystyczną dla krajów niderlandzkich ${ }^{10}$. Biała imprimatura występuje w obrazie Antona Möllera Grosz. çynszony z 1601 r. (il. 3). W późniejszych obrazach artysta zastosował brązowe podmalowanie, sa to: Ucsynki Miłosierdzia (nr 10) z 1607 r. oraz Ukryyżowanie (nr 13), namalowanym w latach 1609-1611. Warto podkreślić, że drugi z obrazów ma wyjątkową dwuwarstwową zaprawę: żółtą i różowa. Odcień różu zaprawy w wielu miejscach partii nieba prześwituje spod błękitnobiałego opracowania chmur. Brązowe podmalowanie zidentyfikowano również w obrazie Św. Elìbieta opatrujaca chorego ( $\mathrm{nr}$ 21) Hermanna Hana, datowanym na lata przed 1625 oraz w dwóch znacznie późniejszych portretach pastorów (nr 23 i 24), pierwszy datowany na ok. 1706, a drugi na ok. 1724 r. Isaac van den Blocke, jako jedyny, pod błękitny modelunek szaty w obrazie $S_{e-}$ rvilius Appius z 1608 r. zastosował czerwone podmalowanie. Herman Han w opracowaniu błękitnych partii, najczęściej nieba (nr 14, 16, 17, 19, 20), z użyciem mieszaniny smalty i bieli ołowiowej bardzo często wykorzystywał szary kolor zaprawy, która także pełniła funkcję półtonów i cieni.

W badanych obrazach powstałych pod koniec XVII i w XVIII w. paleta błękitów uległa zawężeniu. Błękit nie występuje w ogóle, a jeśli został zidentyfikowany, jest to błękitny barwnik organiczny - indygo. W powstałym w warsztacie gdańskim obrazie Portret pastora Michaela Ulmitza (nr 23) z ok. 1706, Portret pastora Johanna Gottrieda Kirscha (nr 24) z ok. 1624, Daniela Kleina indygo zostało nałożone na brązowe podmalowanie, w składzie którego zidentyfikowano czerwone i brązowe pigmenty żelazowe pochodzenia naturalnego, czerń roślinną oraz biel ołowiowa. Światła podnoszono poprzez dodanie do indyga bieli ołowiowej. W obrazie pt. Portret nieokreślonego pastora (nr 25), XVIII w., z warsztatu gdańskiego półtony uzyskano, dodając do błękitu czerni roślinnej. W obrazie z 1746 r. Portret Johanna Sigismunda Ferbera (nr 26) J. B. Hoffmanna światła nałożono w technice alla prima. Ciemne błękity uzyskano poprzez zmieszanie błękitnego barwnika z czernia pochodzenia organicznego i odrobiną bieli ołowiowej. Następnie nałożono błękitny laserunek indygiem. W pozostałych obrazach takich jak: Portret pastora Ephraima Kerstena (1654-1691), Portret pastora Teophilusa Jungiusa

10 B. Szmelter-Fausek, Gdański warsžtat malarski..., s. 25-26. 
(1665-1696), Portret pastora Joannesa Falcta (16..?-1729), Portret pastora Johanna Beniamina Dragheima (1700-1761) nie używano błękitu ${ }^{11}$.

Przeprowadzone analizy opracowania błękitów dały możliwość zestawienia oraz usystematyzowania, w jaki sposób kształtowała się technologia i technika malarstwa gdańskiego w okresie od drugiej połowy XVI do XVIII w. Najczęściej stosowanymi błękitnymi pigmentami były: azuryt naturalny i smalta, rzadziej ultramaryna, a od końca XVII w. indygo. Błękity były opracowane w różnych natężeniach i odcieniach. Kolor był zależny od użytego pigmentu, wielkości zastosowanych ziaren minerałów i cząstek szkła kobaltowego oraz od domieszek takich pigmentów jak między innymi biel ołowiowa, żółcień cynowo-ołowiowa i czerwień organiczna. Istotne znaczenie pełnił kolor imprimatury i zaprawy, a także podmalowania, który niekiedy tworzył półtony i cienie. W malarstwie gdańskim zastosowano białe, szare, żółte i różowe zaprawy oraz białe i brązowe imprimatury. W podmalowaniu pod błękitne opracowanie dominował kolor biały i szary bądź lokalny uzyskany ze zmieszania najczęściej azurytu naturalnego, bieli ołowiowej, czerni roślinnej lub smalty i bieli ołowiowej. Stosowano także brązowe podmalowania uzyskane ze zmieszania czerwieni i brazów żelazowych pochodzenia naturalnego, czerni roślinnej oraz bieli ołowiowej. Pod koniec XVII i w XVIII wieku zauważono ograniczenie stosowania błękitów w malarstwie.

Wykonane badania stanowią bazę danych dotycząca sposobów opracowania błękitów w malarstwie gdańskim i będa pomocne podczas analiz porównawczych z innymi dziełami zarówno szkoły gdańskiej, jak i innych szkół europejskich.

\section{Summary}

\section{The technique of blue painting layers in Gdańsk paintings from the mid-sixteenth to the end of the eighteenth century}

The technique of blue painting layers was analyzed on the example of selected 27 panel paintings made in Gdańsk workshops and origin from the churches and the museums of Gdańsk, Pelplin and Poznań.

\footnotetext{
11 J. Olszewska-Świetlik, Gdański warsz̨tat malarski scbyłku XVII i w XVIII wieku..., s. 14 $-22,36-42$.
} 
The general aim of this work was to analyze and systematize of how the technique and the technology of painting the blue layers had been changing from the mid-sixteenth to the end of the eighteenth century. The commonly used blue pigments were natural azurite, natural ultramarine and smalt, and since the beginning of the eighteenth century the only one blue pigment was organic indigo.

The performed analysis is a database on ways of developing the blue painting layers in Gdańsk School of Painting and it will be helpful when comparing with other works both schools of Gdańsk, as well as the other European schools. 


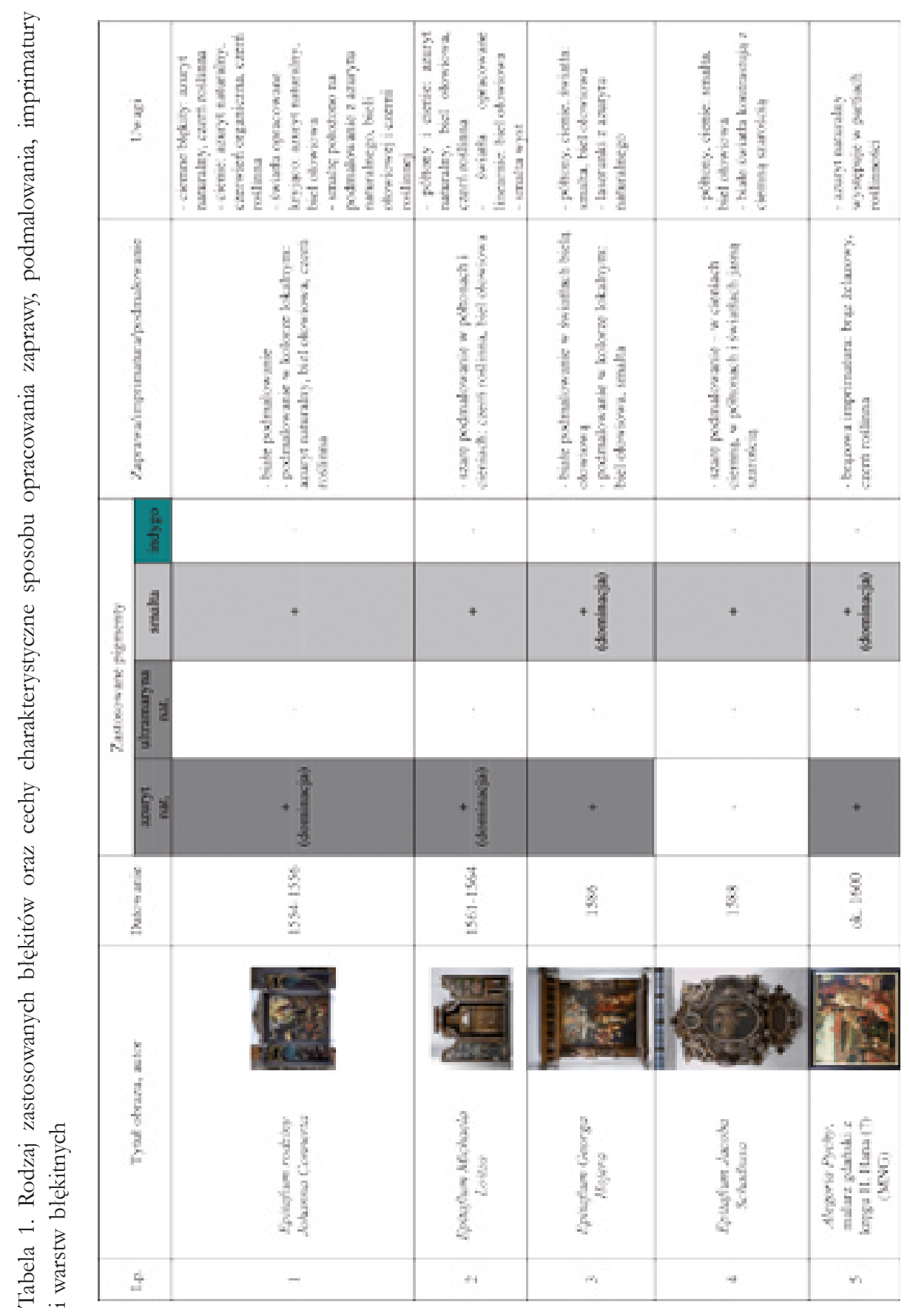




\begin{tabular}{|c|c|c|c|c|c|c|}
\hline 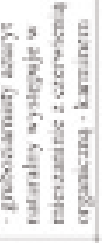 & 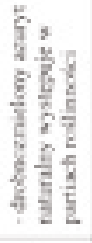 & 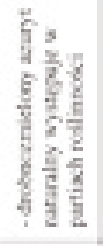 & 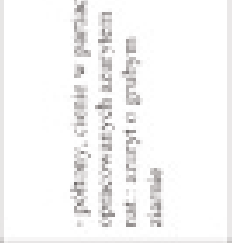 & 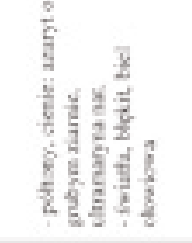 & 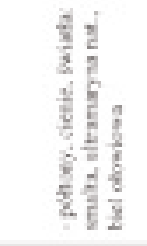 & 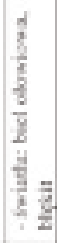 \\
\hline 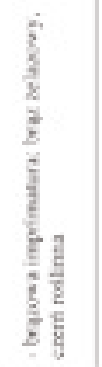 & 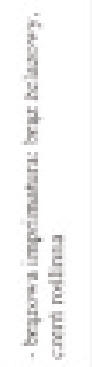 & 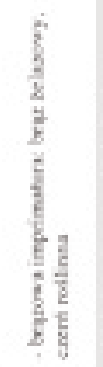 & 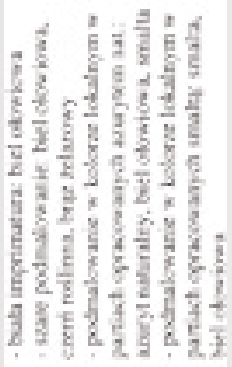 & 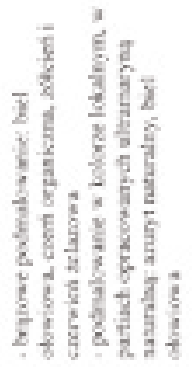 & 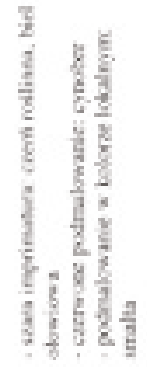 & 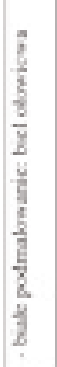 \\
\hline . & & & & &. & $=$ \\
\hline . & - $\frac{a}{\frac{9}{8}}$ & - $\frac{2}{8}$ & - $\frac{8}{8}$ & * & • & $\cdot$ \\
\hline 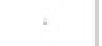 & & & . & + & + & + \\
\hline+ & • & + & + & + & + & + \\
\hline$\frac{\bar{g}}{\mathrm{~g}}$ & $\frac{8}{3}$ & $\frac{6}{8}$ & $\underline{\xi}$ & 8 & z & $\frac{\bar{z}}{3}$ \\
\hline $\mathbb{N}$ & $\approx$ & 28 & & 1502 & $=3$ & 8 \\
\hline 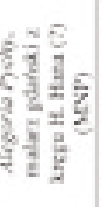 & 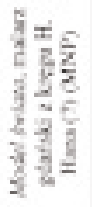 & $\begin{array}{l}3 \\
\frac{3}{2} \\
\frac{2}{3}\end{array}$ & $\begin{array}{l}5 \\
6 \\
5\end{array}$ & 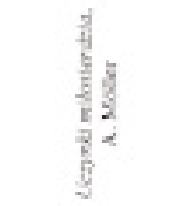 & 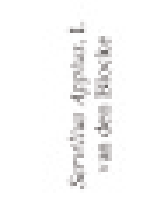 & 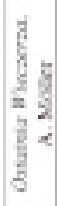 \\
\hline$=$ & $\mathrm{m}$ & x & 0 & 9 & $=$ & \pm \\
\hline
\end{tabular}




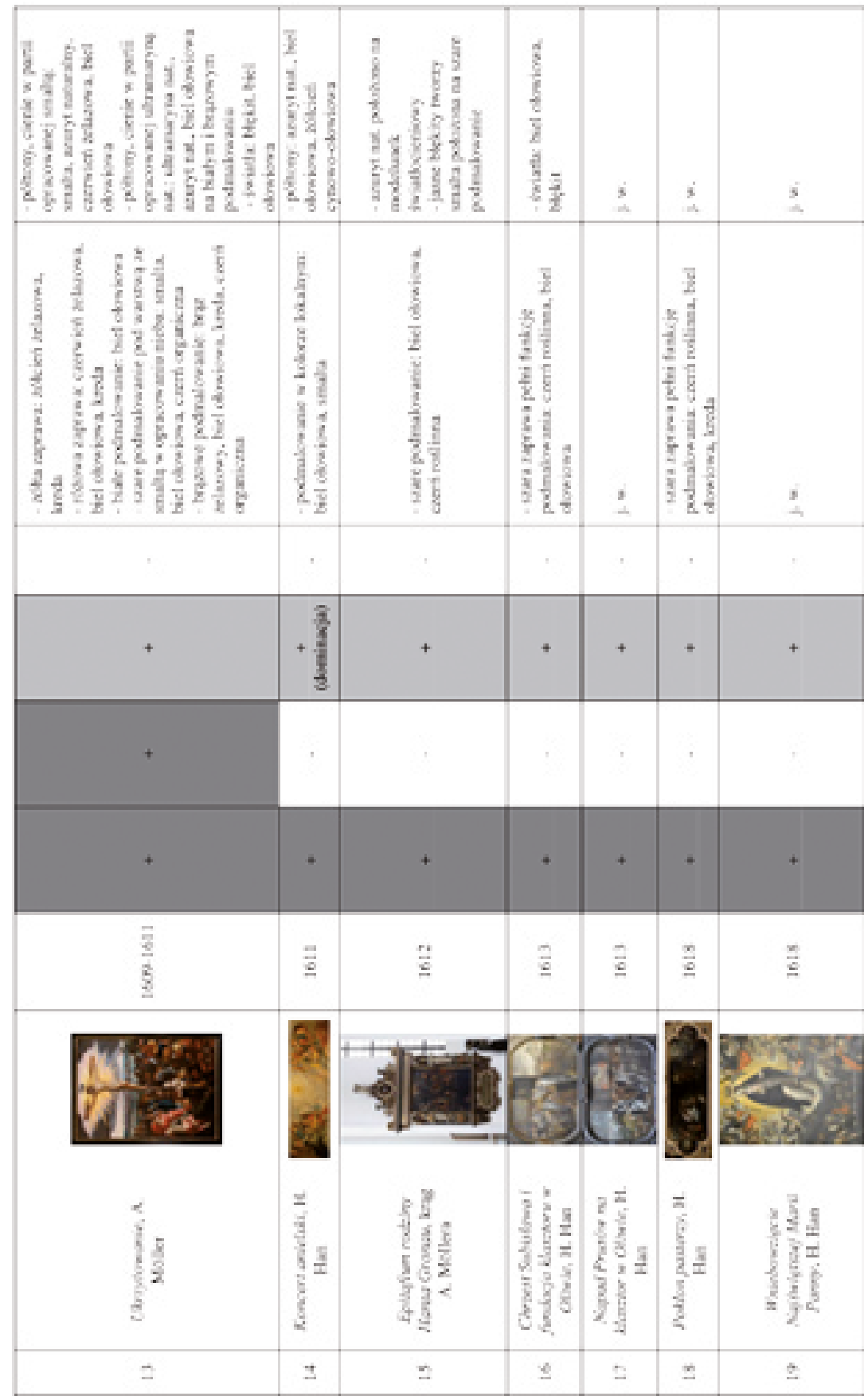




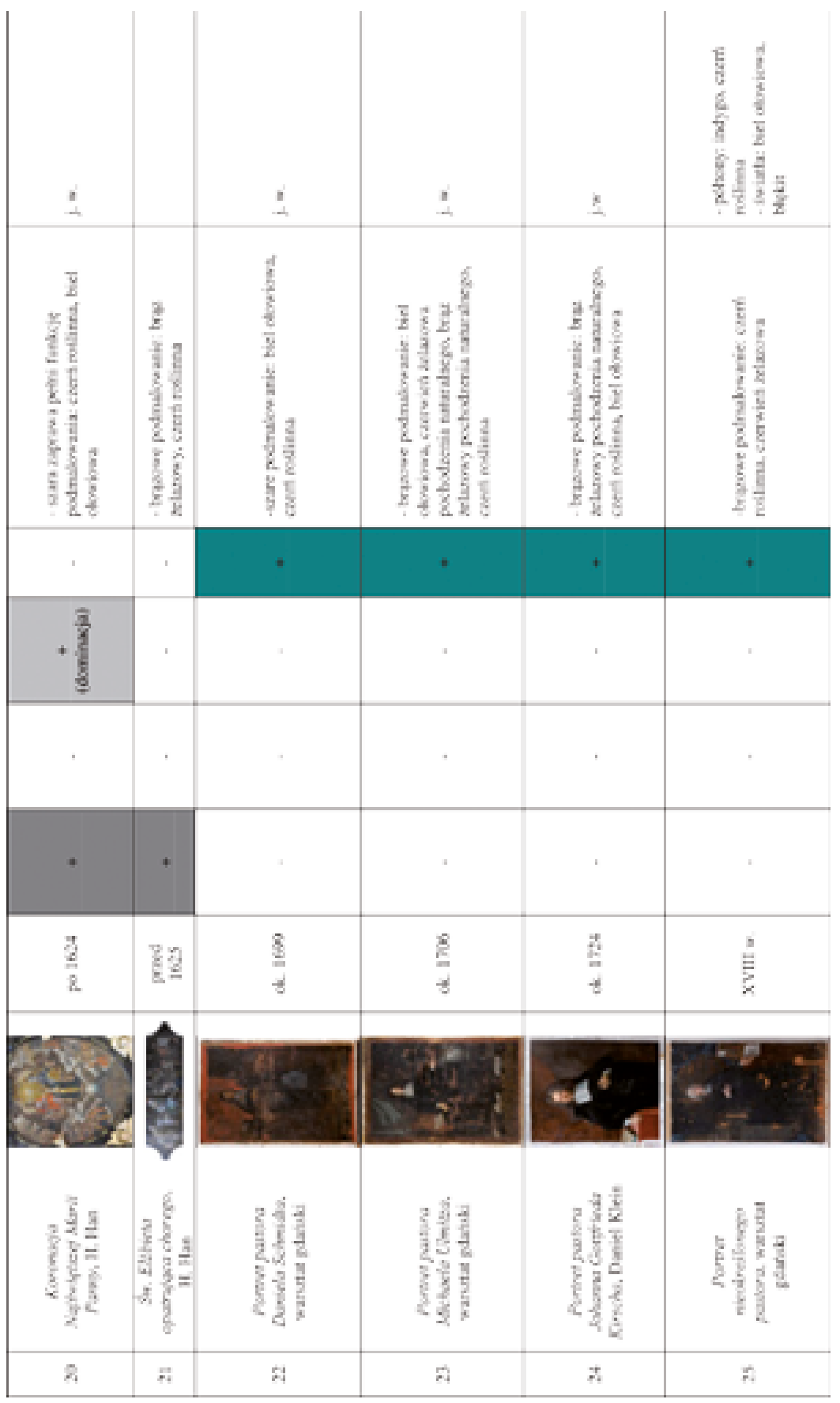




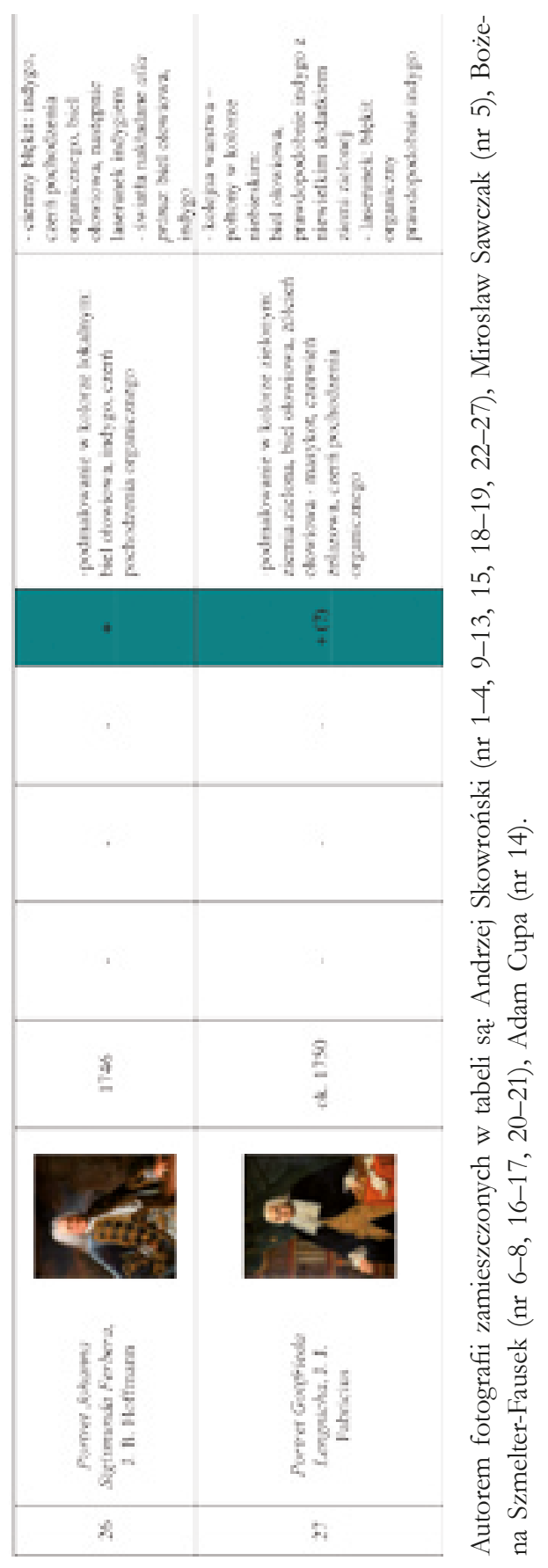



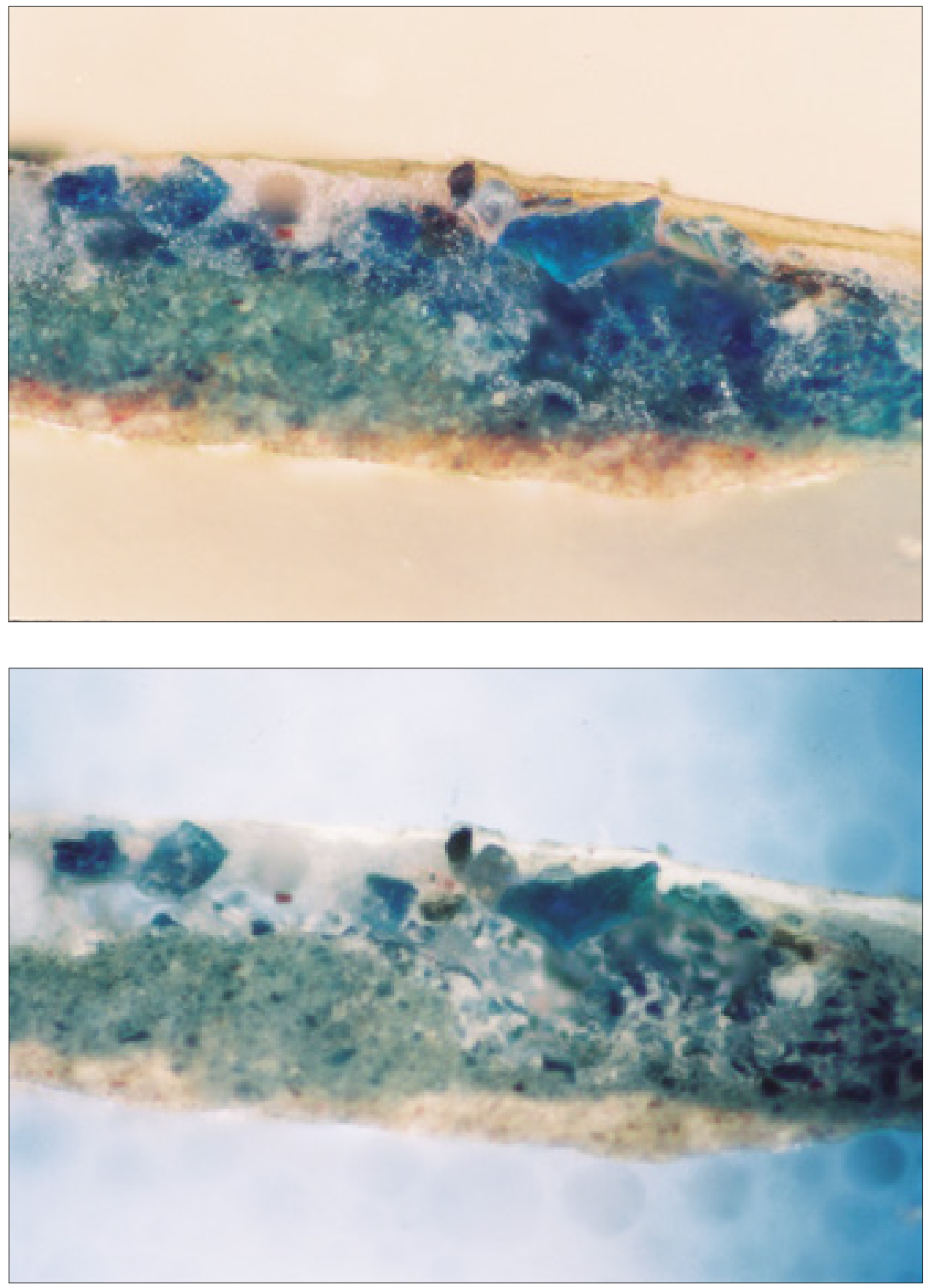

I1. 1. Ucsynki Milościerdzৃia (nr 10), 1607, Anton Möller, mikrofotografie przekroju próbki z błękitnej szaty w świetle VIS i w UV (fot. Z. Rozłucka)

1- brązowa imprimatura: biel ołowiowa $2 \mathrm{PbCO}_{3} \times \mathrm{Pb}(\mathrm{OH})_{2}$, czerń organiczna, żółcień i czerwień żelazowa; 2 - błękitna warstwa malarska: azuryt $2 \mathrm{CuCO}_{3} \times \mathrm{Cu}(\mathrm{OH})_{2}$, ultramaryna naturalna $3 \mathrm{Na}_{2} \mathrm{O} \times 3 \mathrm{Al}_{2} \mathrm{O}_{3} \times 6 \mathrm{SiO}_{2} \times 2 \mathrm{Na}_{2} \mathrm{~S}$, biel ołowiowa $2 \mathrm{PbCO}_{3} \times \mathrm{Pb}(\mathrm{OH})_{2} ; 3$ - błękitna warstwa malarska: azuryt naturalny $2 \mathrm{CuCO}_{3} \times \mathrm{Cu}(\mathrm{OH})_{2}$, ultramaryna naturalna $3 \mathrm{Na}_{2} \mathrm{O} \times 3 \mathrm{Al}_{2} \mathrm{O}_{3} \times 6 \mathrm{SiO}_{2} \times 2 \mathrm{Na}_{2} \mathrm{~S}$, biel ołowiowa $2 \mathrm{PbCO}_{3} \times \mathrm{Pb}(\mathrm{OH})_{2} ; 4$ - werniks wtórny 

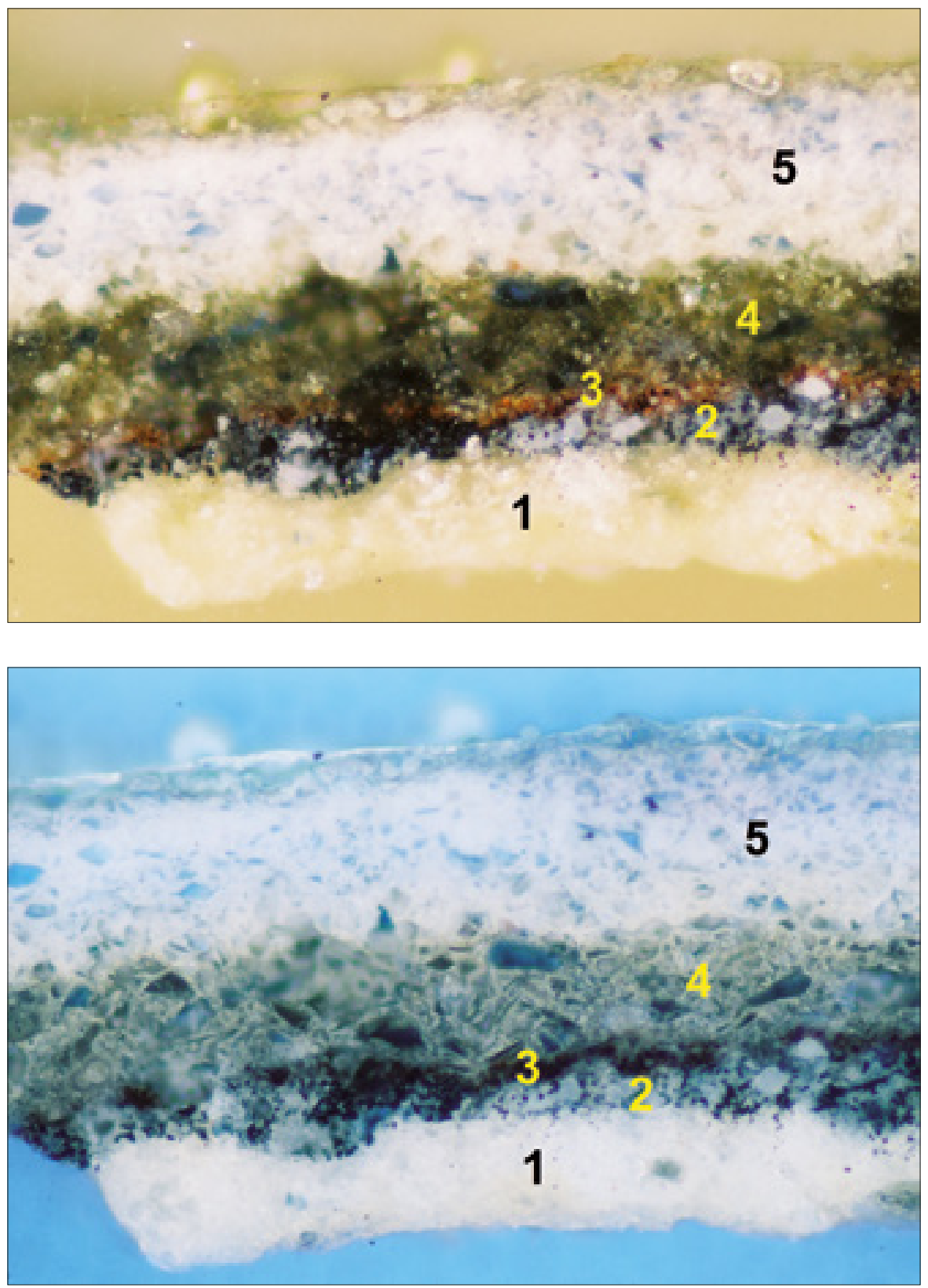

I1. 2. Servilius Appius (nr 11), 1608, Isaac van den Blocke, mikrofotografie przekroju próbki z błękitnej szaty w świetle VIS i w UV (fot. Z. Rozłucka)

1 - biała zaprawa: kreda $\mathrm{CaCO}_{3} ; 2$ - szara imprimatura: czerń roślinna, biel ołowiowa $2 \mathrm{PbCO}_{3} \times \mathrm{Pb}(\mathrm{OH})_{2} ; 3$ - czerwone podmalowanie: cynober HgS; 4 - brązowozielona warstwa malarska: smalta $\mathrm{CoO}$ x $\mathrm{nK}_{2} \mathrm{SiO}_{3} ; 5$ - błękitna warstwa malarska: smalta $\mathrm{CoO}$ x x $n \mathrm{KK}_{2} \mathrm{SiO}_{3}$, ultramaryna naturalna $3 \mathrm{Na}_{2} \mathrm{O} \times 3 \mathrm{Al}_{2} \mathrm{O}_{3} \times 6 \mathrm{SiO}_{2} \times 2 \mathrm{Na}_{2} \mathrm{~S}$, biel ołowiowa $2 \mathrm{PbCO}_{3} \times \mathrm{Pb}(\mathrm{OH})_{2}$ 

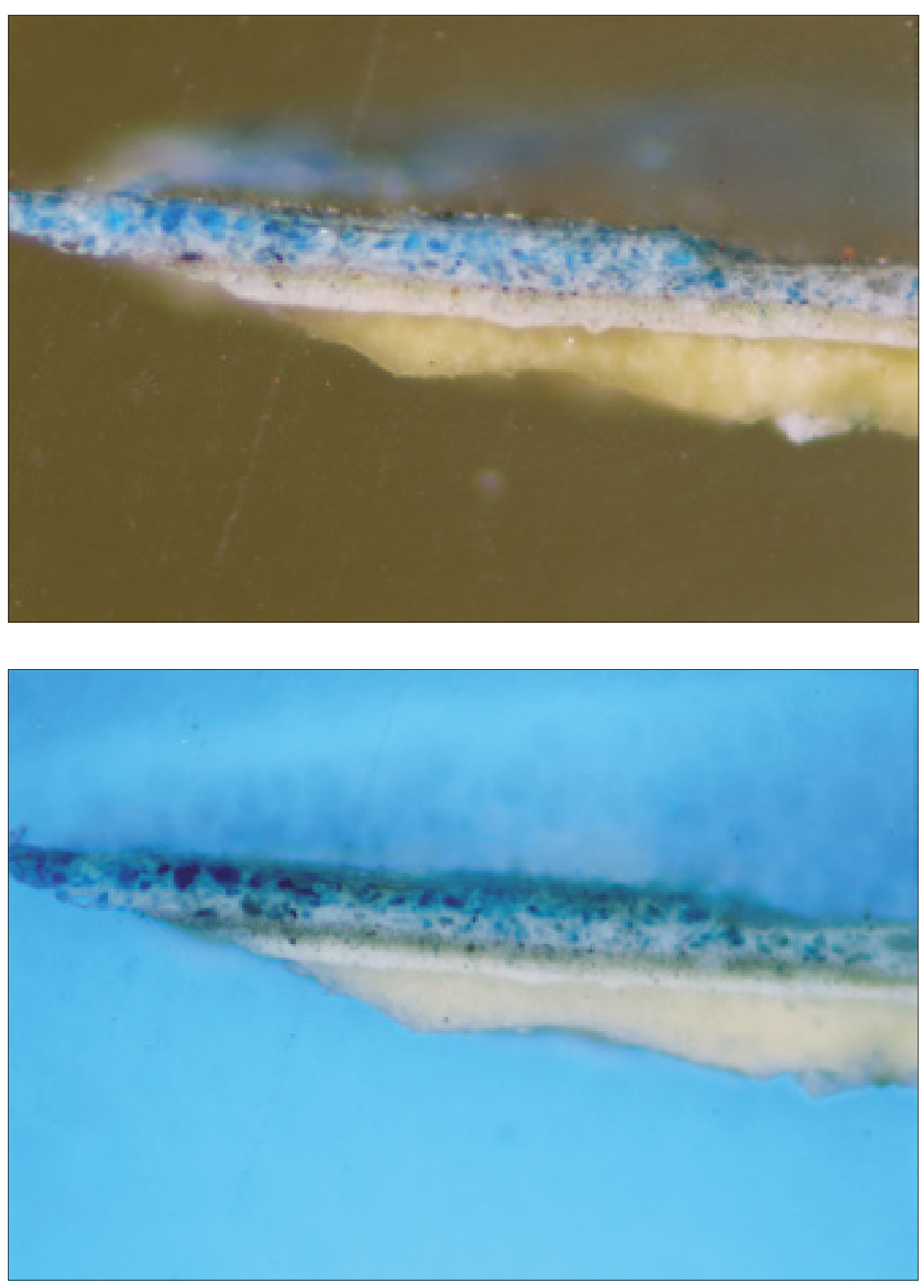

I1. 3. Grosz cąynszony (nr 9), 1601, Anton Möller, mikrofotografie przekroju próbki z błękitnej szaty w świetle VIS i w UV (fot. Z. Rozłucka)

1- biała zaprawa: kreda $\mathrm{CaCO}_{3} ; 2$ - biała imprimatura: biel ołowiowa $2 \mathrm{PbCO}_{3} \times \mathrm{Pb}(\mathrm{OH})_{2}$; 3 - brązowe podmalowanie: biel ołowiowa $2 \mathrm{PbCO}_{3} \times \mathrm{Pb}(\mathrm{OH})_{2}$, czerń roślinna, brąz żelazowy; 4 - błękitna warstwa malarska: azuryt naturalny $2 \mathrm{CuCO}_{3} \times \mathrm{Cu}(\mathrm{OH})_{2}$, smalta $\mathrm{CoO}$ x x nK $\mathrm{SiO}_{3}$, biel ołowiowa $2 \mathrm{PbCO}_{3} \times \mathrm{Pb}(\mathrm{OH})_{2} ; 5$-błękitna warstwa malarska: azuryt naturalny $2 \mathrm{CuCO}_{3} \times \mathrm{Cu}(\mathrm{OH})_{2}$, biel ołowiowa $\left.2 \mathrm{PbCO}_{3} \times \mathrm{Pb}(\mathrm{OH})_{2}\right) ; 6$ - werniks wtórny 
